\title{
Variety of Approaches in Assessment of Global Competitiveness
}

\section{Arpine Sargsyan*}

Theory of Economics, Armenian State University of Economics, Gyumri, Armenia

\begin{abstract}
Competitiveness is one of the most broadly used terms when talking about strengths and weaknesses of a firm, a certain sector of economy, a party, region or state. In its broader sense, competitiveness is used to indicate the ability to achieve certain overall outcomes, such as a high standard of living and economic growth. National Competitiveness as one of the cornerstones in evaluating a country's economy, its potential, is a concept used to define a country's ability to grow, to compete with other countries for human capital, investments, and other resources. Given this importance of the principle, many international organizations, research centres, individual researchers conduct brief researches and analysis, do define, examine competitiveness, and it's driving factors, ways of achievements and improving a country's state in the Global Marketplace.

Many national, international, governmental and non-governmental organizations assess competitiveness taking different viewpoints and sides of the given phenomenon. These approaches are based on different sets of indicators, thus have different measures and results. In this paper, we purpose to define the term competitiveness give its brief overview, list core components, and examine different approaches and methodologies of assessment.
\end{abstract}

Keywords: Competitiveness; Globalization; Measures; Factors; Analysis; Theory; Component-indicators; Pillar; Observe; Calculation; Index

\section{Introduction to Global Competitiveness}

Global competitiveness is a multidimensional concept and has various definitions.

Thus, according to Rapkin, et al. competitiveness is “.... political and economic concept that affect military, political and scientific potential of the country and is an integral factor in the relative position of the country in the international political economy. ${ }^{1}$

Krugman defines competitiveness as a concept equivalent of productivity. On the other hand, he claims that competitiveness is "wrong and dangerous definition" if to apply for the international level'.

According to Porter [1], this concept deals with the policy and institutions in the state that promotes long-term growth. "National competitiveness" corresponds to the economic structures and institutions of the state for economic growth within the structure of global economy ${ }^{3}$.

Another outstanding definition states, that competitiveness “... refers to a country's ability to create, produce, distribute, and/or service products in international trade while earning rising returns on its resources"4.

Kulikov claims that there are real and nominal competitiveness. Real competitiveness requires openness and fairness of markets, the quality and innovation of products and services in the country of origin and the continued growth of life standard of its citizens. Therefore, the actual degree of competitiveness is a possibility of national industries to have a free and fair market of goods and services that meet the requirements of both domestic and foreign markets, and simultaneous

${ }^{1}$ National Competitiveness in a Global Economy (Advances in International Political Economy) // by David P Rapkin, William P Avery (1995)

${ }^{2}$ http://88.167.97.19/temp/Paul_Krugman_-_Competitiveness_A_dangerous_obsession.pdf

${ }^{3}$ The Competitive Advantage of Nations // by Michael E. Porter, 1998

${ }^{4}$ Scott and Lodge, 1985, p. 3 growth of real income. Since the nominal competitiveness can be achieved by a particular government policy, creating a macroeconomic environment for domestic producers through direct state subsidies and wage restraint [2]. Thus, the real competitiveness is possible only if national companies are able to effectively design, produce goods and sell them at prices and quality that meets both external and internal customers' requirements - without direct subsidies, control of wages and unemployment ${ }^{5}$.

Thus, it can be inferred, that competitiveness reflects the favourable position of the national economy in the global space. This position can be reflected in many areas, mainly in the field of international trade as the country's ability to strengthen this position.

The competitiveness of the national economy is its concentrated expression of economic, scientific, technological, organizational, managerial, marketing and other capabilities [3]. This concept embodies an ability of a state to achieve high rates of economic growth, ensure a steady increase in real wages, promotion of domestic firms on the world market.

In this regard, economies that are more competitive tend to be able to produce higher levels of income for their citizens, thus achieve a higher level of the quality of life. In other words, competitiveness can be described as the ability of an economy to produce, promote and sell goods and services in the global economy.

${ }^{5}$ Management of Competitiveness: Theory and Practice: // by Alexander Chursin,Yury Makarov // Moscow, Russia, 2015, p. 9.

${ }^{*}$ Corresponding author: Arpine Sargsyan, Ph.D. Student, Chair of Theory of Economics, Armenian State University of Economics, Gyumri, Armenia, Tel: 00374 77644577; E-mail: arpinesargsyan1994@gmail.com

Received November 10, 2017; Accepted November 30, 2017; Published December 04, 2017

Citation: Sargsyan A (2017) Variety of Approaches in Assessment of Global Competitiveness. Int J Econ Manag Sci 6: 479. doi: 10.4172/2162-6359.1000479

Copyright: ( 2017 Sargsyan A. This is an open-access article distributed under the terms of the Creative Commons Attribution License, which permits unrestricted use, distribution, and reproduction in any medium, provided the original author and source are credited. 
It can be inferred, that a more competitive economy is the one that is likely to grow faster over the medium to long run.

The term itself came into use in the USA, in 1985. Than it became famous worldwide. Nowadays the principle of competitiveness is one of the most important components of qualitative analysis, trying to assess a country's attractiveness and its engagement in global processes.

Given this importance of maintaining competitiveness, governments of different countries targeted their policies towards becoming more competitive and gaining their niche in this globalized world [4-6]. Thus, national governments' principal goal is to establish an environment that fosters wellbeing for its citizens by addressing health, safety, environmental issues and laws. Undoubtedly, this goal can be achieved through effective management and allocation of resources, and active political interventions. Therefore, it becomes imperative for governments to coordinate a comprehensive approach towards trade and investment that incorporates a competition orientation ${ }^{6}$. However, governmental bodies and decision makers must be cognizant of the fact that their nation's competitiveness depends upon their ability to sustain trade and attract foreign investment [7].

\section{Theoretical and Empirical Approaches to Understanding and Measuring Global Competitiveness}

Competitiveness is, perhaps, one of the widely discussed, criticized phenomena of international economics. This fact explains existing of many theories discussing features of competitiveness.

Global competitiveness owes its origin to the theory of comparative advantage, which historically was an antithesis to the perspective of the mercantilists. They believed in exports and recommended strict government control of all economic activity with economic nationalistic ideas. Mercantilists' approach became a cornerstone to the many other theories that came into use later. Among them are Ricardo's theory of comparative advantage and Heckscher-Ohlin's factor abundance theory (according to this theory, countries will produce and export those goods and services in which they have a comparative advantage in price or factor cost). Initially Heckscher-Ohlin's theory takes two factors as basic indicators determining competitive advantages. Later some studies went beyond the two-factor analysis.

Another theory is ascribed to the Bank of England. According to this theory, competitiveness should be measured in terms of relative indicators (i.e. relative export prices, relative export productivity, relative unit labor cost, etc.).

Using a slightly different approach, the Economics and Statistics Department of Organization for Economic Cooperation and Development (OECD) measures competitiveness as a sum of export and import competitiveness.

One of the most well-known theories of national competitiveness is Michael Porter's 'National Diamond', which represents a useful grouping of the concepts appropriate to analysis of competitiveness and trade, thus is usually viewed in the context of case studies used to assess the prospects of an industry, product or economic activity. According to prof. Porter, there are four driving factors, cornerstones in the competitiveness, entitled as "diamond";

${ }^{6}$ Feketekuty, 1996

${ }^{7}$ Institute For Strategy and Competitiveness, About Michael Porter, available at http://www.isc.hbs.edu/about-michael-porter/Pages/default.aspx

${ }^{8}$ Porter Diamond, see at http://www.investopedia.com/terms/p/porter-diamond. asp\#ixzz4nxhTAAAO
Many international, national, non-governmental organizations assess the level of competitiveness of various countries.

Historically the first attempt made by the IMD World Competitiveness Center", which publishes its "World competitiveness yearbook" since 1989. One of the most outstanding characteristics of the WCY is that it is the first comprehensive annual report and a worldwide reference pointing on the competitiveness of countries. The yearbook provides benchmarks and trends, statistics and survey data based on extensive research. According to the WCY a country's competitiveness is assessed and ranked according to how they manage their competencies to achieve long-term value creation. According to the methodology report published by the IMD World Competitiveness Center, an economy's GDP and productivity cannot be assesses as the only important indicators for its competitiveness, political, social and cultural dimensions also play a vital role in the process of formatting competitive advantages ${ }^{10}$. Thus, governments need to provide an environment for business enterprises. This environment is to be characterised by efficient infrastructures, institutions and policies that encourage sustainable value creation by these enterprises.

According to the WCY, observed countries' ranking is calculated as the composite index. The latter is based on nearly 340 indicators that measure competitiveness. Comparative data on the abovementioned indicators are collected through various international, national, regional sources, statistic databases, as well as from surveys conducted within business communities, government agencies. The above-mentioned indicators are grouped in four major sets described as follows.

1. A country's economic Performance (assessed through 78 macroeconomic indicators);

2. Government Efficiency (government policy supports national competitiveness or not). These set includes 70 indicators;

3. Business Efficiency - 67 indicators;

4. Infrastructure (do they fulfil business requirements or not) 114 indicators.

The above-mentioned indicators are described in detail in the Table 1 .

Each of these four sets is, in turn, divided into 5 sub-sectors. Thus, the ranking is based on 20 sub-factors. When describing the methodology of the WCY, it should also be noted that the methodology has changed since 1989. These changes have been applied in accordance with the challenges and changes of the global economy. It is notable, that WCY methodology relies on four dimensions shaping a country's competitiveness and determining countries' development strategies and participation in international division of labour. These four dimensions are listed as follows;

1. Attractiveness vs. aggressiveness;

2. Proximity vs. globalism;

3. Assets vs. processes;

4. Individual risk taking vs. social cohesiveness.

To sum up, the WCY methodology emphasizes the multifaceted

${ }^{9} \mathrm{https} / / / \mathrm{www}$.imd.org/wcc/world-competitiveness-center-mission/centerhistory-bris-garelli/

${ }^{10} \mathrm{https}$ ://www.imd.org/globalassets/wcc/docs/methodology-and-principleswcc-2017.pdf 


\begin{tabular}{|c|c|c|c|}
\hline Economic performance & Government's efficiency & Business efficiency & Infrastructure \\
\hline $\begin{array}{l}\text { Macroeconomic evaluation of } \\
\text { the domestic economy ( } 5 \text { sub- } \\
\text { factors) }\end{array}$ & $\begin{array}{l}\text { Extent to which government policies } \\
\text { are conductive to competitiveness ( } 5 \\
\text { sub-factors) }\end{array}$ & $\begin{array}{l}\text { Extent to which enterprises are } \\
\text { performing in an innovative, profitable and } \\
\text { responsible manner ( } 5 \text { sub-factors) }\end{array}$ & $\begin{array}{l}\text { Extent to which basic, technological, scientific and } \\
\text { human resources meet the needs of business ( } 5 \\
\text { sub-factors) }\end{array}$ \\
\hline Domestic, economy, & Public finance & Productivity & Basic infrastructure \\
\hline International trade & Fiscal policy & Labour market & Technological infrastructure \\
\hline International investment & Institutional framework & Finance & Scientific infrastructure \\
\hline Employment & Business legislation & Management practices & Health and environment \\
\hline Prices (78 criteria) & Societal framework (70 criteria) & Attitudes and values (67 criteria) & Educations (96 criteria) \\
\hline
\end{tabular}

Table 1: Indicators are grouped in four major sets.

\begin{tabular}{|c|c|c|}
\hline Basic requirements & Efficiency enhancers & Innovation and sophistication \\
\hline Institutions & Higher education and training & Business sophistication \\
\hline Infrastructure & Goods market efficiency \\
\hline Macroeconomic environment & Labor market development \\
\hline Health and primary education & Financial Market development \\
\hline & Technological readiness \\
\hline
\end{tabular}

Table 2: 12 pillars are grouped in 3 sub-indexes.

\begin{tabular}{|c|c|c|}
\hline Fixed & Hard & Soft \\
\hline $\begin{array}{l}\text { These conditions are invariant and } \\
\text { cannot be changed }\end{array}$ & These conditions can be changed but not quickly & $\begin{array}{l}\text { Refer to government policy and can be } \\
\text { changed easily }\end{array}$ \\
\hline $\begin{array}{l}\text { (Geography, topography, natural } \\
\text { resource endowment, culture, history, } \\
\text { climate, etc.) }\end{array}$ & $\begin{array}{l}\text { (The quality of institutions, industrial structure, ownership, public attitudes, } \\
\text { composition of economic output, level and quality of human and physical capital } \\
\text { stocks, etc.) }\end{array}$ & $\begin{array}{l}\text { (Tax code, international relations } \\
\text { and agreements, laws, regulating } \\
\text { frameworks, etc.) }\end{array}$ \\
\hline
\end{tabular}

Table 3: Three main types or initial conditions in transition.

nature of the competitiveness concept. One of the outstanding characteristics of this methodology is that it aggregates a set of indicators, which determine the overall competitiveness index and rankings of the countries included in the WCY database.

Another well-known and broadly used approach in assessment of the competitiveness is The Global Competitiveness Report (Index) published (measured) by the World economic forum international organization $^{11}$. The Report was first published in 1979, when the world was facing the worst and longest lasting financial and economic crisis of the last 80 years - in order to get the pre-crisis situation. The Global Competitiveness Report ranks countries based on the Global Competitiveness Index (calculated since 2004), taking into account the country's ability to ensure welfare for their citizens, which depends on the effectiveness of using all resources of a given country.

The Global Competitiveness index is a comprehensive tool, that measures the competitiveness of 148 countries, contains 3 sub-indexes: basic requirements, efficiency enhancers, innovation and sophistication factors that are based on 12 pillars (institutions, infrastructure, macroeconomic environment, health and primary education, higher education and training, etc.) including 119 indicators 12 pillars of competitiveness are:

1. Institutions;

2. Infrastructure;

3. Macroeconomic environment;

4. Health and primary education;

5. Higher education and training;

6. Goods market efficiency;

7. Labour market efficiency;

${ }^{11}$ https://www.weforum.org/reports/the-global-competitiveness-report-2017-2018
8. Financial market development;

9. Technological readiness;

10. Market size;

11. Business sophistication;

12. Innovation.

The 12 pillars are grouped in 3 sub-indexes described below in Table 2 .

The GCI is calculated as a weighted average of its components. The Harvard Institute proposes one of well-known methodologies in assessment of competitiveness for International Development (HIID). This methodology assesses competitiveness as the ability of a national economy to achieve sustained high rates of economic growth, mainly focusing on the competitiveness possibilities of economies in transition. The HIID mainly follows the theoretical and methodological approaches of GCR and is based on the WEF's competitiveness definition presented in the Global Competitiveness Report. The main feature of this methodology is that it puts emphasis on the initial conditions of transition and the ability of the countries to improve the competitive positions of their economies. Thus, the HIID differentiates three main types or initial conditions in transition, presented in the Table 3.

The HIID calculates the overall competitiveness index basing on scores of its indices or factors, collecting statistical data of international and national organizations and of survey data.

The HIID overall competitiveness index is composed of the following components;

- Openness of the economy,

- Government's efficiency, 
Citation: Sargsyan A (2017) Variety of Approaches in Assessment of Global Competitiveness. Int J Econ Manag Sci 6: 479. doi: 10.4172/21626359.1000479

- Infrastructure,

- Technology,

- Financial sector,

- Efficiency of institutions,

- Management and labour.

\section{References}

1. Porter ME (2003) The Economic Performance of Regions. Regional Studies 37: 549-678.

2. Kitson M, Martin R, Tyler P (2004) Regional Competitiveness: An Elusive yet
Key Concept? Regional Studies. 38: 991-999.

3. Kravis IB, Lipsey RE (1992) Sources of Competitiveness of the United States and of its Multinational Firms. The Review of Economics and Statistics 74: 193-201.

4. Lall S (2001) Competitiveness, Technology and Skills. Vermont: Edward Elgar Publishing.

5. Buckley PJ, Pass CL, Prescott K (1990) Measures of International Competitiveness: Empirical Findings from British Manufacturing Companies. Journal of Marketing Management 6: 1-13.

6. Budd L, Hirmis AK (2004) Conceptual Framework for Regional Competitiveness Regional Studies 38: 1015-1028.

7. Garelli S (2007) Competitiveness of Nations: The Fundamentals: IMD World Competitiveness Center. 